\title{
Efficiency of Immunization of Mice with Irradiated Antigen Against Schistosoma mansoni Infection in Comparison with Praziquantel
}

\author{
Mona A. El-Gawish, Manar N. Hafez, Fatma A. Eid* Maha G. Soliman* and \\ Shymaa M. Khalil* \\ National Center for Radiation Research and Technology. Faculty of Science \\ Al-Azhar University*
}

\begin{abstract}
Introduction: The present study is an attempt to evaluate the protective effect of schistosomula antigen and the current antischistosomal drug praziquantel (PZQ) as a reference drug on mice infected with $S$. mansoni.

Material and Methods: Mice were vaccinated by irradiated or non-irradiated schistosomula antigen, both at a dose of 100 ug protein/mice once weekly for 3 weeks, before infection with alive cercariae and compared with the treatment with i.m. injection of praziquantel at a dose of $40 \mathrm{mg} / \mathrm{kg}$ b.wt. 4 times once weekly for 4 weeks after infection. The degree of resistance or protection induced by immunization and chemotherapy was assessed 45 days post-infection and evaluated by physiological, parasitological, immunological as well as histological parameters.
\end{abstract}

Results: The results indicated that immunization with $\gamma$-irradiated antigen at $20 \mathrm{Krad}$ or the treatment with PZQ resulted in significant reduction in ova count in liver and intestine tissues more than those vaccinated with non-irradiated antigen compared with infected group. Immunized group with irradiated antigen and the group treated with PZQ showed a significant decrease in liver enzymes activity (ALT, AST and $\gamma$-GT), while in immunized group with nonirradiated antigen, there was a significant increase in AST and $\gamma$-GT as compared to infected group. The level of alkaline phosphatase enzyme was significantly increased in all investigated groups compared to infected one. Treatment with PZQ or immunization with irradiated or nonirradiated schistosomula antigen induced amelioration in serum IL-10 and TNF- $\alpha$. Scanning electron microscope demonstrated normal mature worms in infected group after 45 days from infection. In contrast, many changes were detected in the rest groups as alterations in the tegument, implosion of tubercles which appeared pealed and sloughed off and most of the spines were detached and separated.

Histological examination of liver sections of infected mice revealed lobular cellular infiltration and cloudy swelling in hepatocytes with occurrence of necrotic foci. Also, granuloma of infiltrating cells was noticed around the portal structures and inbetween the degenerated cells. Congested portal vein could be seen lodged with adult worms and the portal tracts showed fibrous thickening. Whereas, the lung revealed destructed bronchioles which appeared surrounded by intense inflammatory foci. Thickened interalveolar septae were also marked, however many alveoli appeared with shed destroyed epithelium. Moreover, peribronchiolar and perivascular fibrosis was quite prominent. Gross pathological alterations were observed in both liver and lung of immunized groups with non-irradiated antigen. In controversy, immunization with irradiated antigen can reduce the granulomatous reaction and collagen deposition. There are also little inflammation and less congestion, however the hepatic and pulmonary architectures appeared otherwise normal. The present histological findings proved that PZQ has a valuable schistosomicidal effect but some pathological changes are still detectable.

Conclusion: On the whole, it could be concluded that irradiated antigen produced marked protection against S.mansoni infection and this may reflect its possible beneficial effect on the diseased liver and lung. 


\section{Mona A. El-Gawish et al}

\section{Introduction}

Current strategies for the control of schistosomiasis are based primarily on chemotherapy. In recent decades, praziquantel is the drug of choice. Praziquantel has high cure and egg reduction rates with non or only mild side effects (Kumar and Gryseels, 1994). However, it does not prevent re-infection and laboratory data raised considerable concern that praziquantel tolerance and/or resistance may be developed (Fallon and Doenhoff, 1994).

In Egypt, schistosomiasis unfortunately remains a major public health problem. Production of an effective schistosomiasis vaccine has proved to be elusive but the protective immunity induced by radiation-attenuated larvae may give a hope for millions of people allover the world.

The immune response against schistosoma infection is a complicated reaction that involves the recruitment of various epitopes and the activation of different types of cells with different levels of cytokine production. In 2004 De Jesus et al. evaluated the role of cytokines in hepatic fibrosis in the prehepatosplenic and early hepatosplenic stages of schistosomiasis . In some reports, TH1 and $\mathrm{TH} 2$ were both involved in antischistosomal immunity (Hoffmann et al., 1999). El-Kady et al. (2005) stated that Schistosoma mansoni infection is characterized by a strong $\mathrm{T}$ helper type 2 (Th2) cell-associated immune response.

According to Delgado et al. (2002), $S$. mansoni was responsible for lesions that can alter the hemodynamic of the hepatic portal venous circulation as well as lung arterial and venous systems. In 1997 Ozaki et al. stated that all infected mice harbored the schistosomes in their lungs at 10-12 weeks post-infection, showing the distinct relocation of adult worms in the lungs and hepatic portal vein. In this regard, Cheever et al. (2002) found granulomatous inflammation and fibrosis in the liver in models of acute and chronic infection. Also, Vennervald et al. (2004) reported that hepatosplenic schistosomiasis involved organomegaly, portal fibrosis and portal hyperte- nsion. In S. mansoni infection, the chronic egg-induced granulomatous response in the liver and intestine may eventually cause extensive tissue scarring and development of portal hypertension. Much of the morbidity and mortality associated with this disease was directly attributed to the deposition of connective tissue elements in affected tissues (Wyan et al., 2004).

Praziquantel (PZQ) was highly effective against all species of schistosomes and showed some adverse effects (Greenberg, 2005). Effect of PZQ on the eggs of S.mansoni was studied by Botros et al. (1996) who found that PZQ in a dose of $50 \mathrm{mg} / \mathrm{kg}$ for two consecutive days 7 weeks post-infection caused complete eradication of worms, disappearance of immature egg stages, decrease in the number of mature eggs and an increase in the number of dead eggs. However, Liang et al. (2002) observed pathological changes occurred by schistosome egg-granulomas in the liver of infected mice after treatment with PZQ. Many persons who come in contact with cercariae of $S$. mansoni several times may be infected again post-chemotherapy treatment. Thus the present work aims to investigate an irradiated schistosomula antigen to give permanent immunity against the infection with $S$. mansoni. So the present study was designed to demonstrate the physiological, parasitological, immunoresponse and histopathological changes occurred in male albino mice infected with S.mansoni cercariae and either treated with PZQ or immunized with non-irradiated and irradiated antigens.

\section{Material and Methods}

\section{1- Experimental design and animal groups}

A total number of 100 Swiss albino male mice aged 5 weeks weighing 20-25 g were divided into:

Group 1: Control (untreated group).

Group 2: Infected with alive normal $S$. mansoni cercariae.

Group 3: Treated with antibilharzial drug 
praziquantel $(40 \mathrm{mg} / \mathrm{Kg}$ b.wt., i.p., once weekly for 4 weeks) after infection with alive $S$. mansoni cercariae.

Group 4: Immunized with 100 ug of nonirradiated schistosomula antigen and then infected with alive $S$. mansoni cercariae.

Group 5: Immunized with 100 ug of irradiated schistosomula antigen at $20 \mathrm{k}$ rad once weekly for 3 weeks and then infected with alive $S$. mansoni cercariae

All groups were sacrificed after 45 days of subcutaneous infection with 100 alive $S$. mansoni cercariae / mouse.

\section{2-Preparation of schistosomula homoge- nate for immunization}

Schistosomula were obtained from infected hamsters obtained from Theodore Bilhars Research Institute (T.B.R.I.), after 7-10 days of infection with $S$. mansoni cercariae through perfusion technique using citrated saline.

The collected schistosomula were washed several times in phosphate buffer solution (PBS) (PH 7.2) and divided into 2 portions. The first portion was exposed to $20 \mathrm{Krad}$ of gamma-radiation (Harrison et al., 1990) and the second portion was kept unirradiated. The two portions were homogenized for 10 minutes and centrifuged for 20 minutes and the resulting supernatant was considered as the crude antigen and its protein content was determined as described by Henry (1976) and kept frozen at $-20^{\circ} \mathrm{C}$ till use.

\section{3- Irradiation facilities}

The irradiation process of schistosomula was performed using ${ }^{60} \mathrm{Co}$ gamma chamber $4000 \mathrm{~A}$ irradiator at the National Center for Radiation Research and Technology. Schistosomula homogenate was irradiated $(20 \mathrm{~K} \mathrm{rad})$ at a dose rate of $0.9125 \mathrm{Kgy} /$ hour at the time of experiment.

\section{4- Praziquantel treatment}

Praziquantel was obtained from pharco pharma in the form of tablets, each tablet contained $600 \mathrm{mg}$ of PZQ. It was dissolved in a little amount of DMSO and then completed to the appropriate volume with saline.

\section{5-Infection of animals}

Mice were subcutaneously infected with newly shed alive cercariae of $S$. mansoni. Each mouse was infected with 100 alive cercariae.

\section{6- Physiological analysis}

Blood was collected by decapitation and serum was then separated by centrifugation at $3000 \mathrm{rpm}$ for $10 \mathrm{~min}$ and preserved at $-20^{\circ} \mathrm{C}$ for determination of biochemical analysis. Gamma-glutamyl transferase $(\gamma-\mathrm{GT})$, alkaline phosphatase, alanine amino transferase (ALT) and aspartate amino transaminase (AST) were measured according to Young (2001), Scand (1974) and Schumann and Klauke (2003) respectively. Serum Mouse TNF- $\alpha$ and IL-10 were assayed by Enzyme Linked-Immuno-Sorbent Assay (ELISA).

\section{7- Ova count}

A piece of the liver tissue was taken from each mouse to find out the number of eggs / gm tissue using $\mathrm{KOH}$ according to Kamel et al. (1978).

\section{8- Hepatic perfusion}

Perfusion was carried out 45 days post-infection for worm burden according to Yolles et al. (1947) technique.

\section{9- Percentage of resistance}

Measurement of protection was determined as described by Wilson and Coulson (1986). The percentage of resistance $=\mathrm{C}-\mathrm{V} / \mathrm{C}$ X 100 where $\mathrm{C}=$ mean number of worm burden in unimmunized mice, $\mathrm{V}=$ mean number of worm burden in the immunized group.

\section{0- Scanning electron microscopy}

Freshly perfused $S$. mansoni adult worms from all animal groups were fixed in $4 \%$ gluteraldehyde and $0.2 \mathrm{M} \quad \mathrm{Na}-$ Cocadylate $(\mathrm{v} / \mathrm{v})$ and then processed for SEM according to Fallon et al. (1996). Specimens were examined at high magnification x 200000 and resolution is $4 \mathrm{~nm}$ using JEOL-JSM-5400 scanning electron microscope at the National Center for Radiation Research and Technology, Cairo. 


\section{Mona A. El-Gawish et al}

\section{1- Histopathological preparations}

Following sacrifice of mice both liver and lung were rapidly removed, rinsed in saline solution, and fixed in $10 \%$ formalin. Sections of $5 \mu$ thickness were cut and stained with haematoxylin and eosin (Drury and Wallington, 1980) and Masson's trichrome (modified from Masson, 1929).

\section{2- Statistical evaluation}

The statistical analysis was performed according to Arkin and Colton (1962).

\section{Results}

\section{1- Physiological analysis}

Serum $\gamma$-GT in infected group was significantly increased (61.3\%) as compared with control group. The treatment with PZQ after infection improved the level of $\gamma$-GT and the increase was lower than the infected group (29.96 $\%$ ). On the other hand, immunization of infected mice with irradiated schistosomula antigen $(20 \mathrm{Krad})$ restored the level of serum $\gamma$-GT and its value returned to normal. In contrast, immunization of infected mice with non-irradiated antigen induced highly significant increase (97.32 $\%-\mathrm{P}<0.001)$ as compared to control group (Table 1).

Infected mice exhibited highly significant increase in serum alkaline phosphtase level; such increase reached $53.35 \%$ as compared with control. Immunization of infected mice with irradiated or non-irradiated schistosomula antigen as well as the treatment with PZQ showed a highly significant increase in alkaline phosphatase recorded 66.83, 133.09 and $134.24 \%$ respectively (Table 1 ).

The data in table (2) revealed that serum ALT in infected group was highly increased reached $178.88 \%$ as compared with control group. Such increase in serum ALT was also recorded in the investigated groups.

The same trend was also observed in serum AST in all investigated groups. The more pronounced percentage of increase was observed in mice immunized with non- irradiated schistosomula antigen (314.25\%) as compared with control group (Table 2).

\section{2- Parasitological analysis}

Vaccination with $\gamma$-irradiated antigen or PZQ treatment resulted in significant reduction in ova count in liver (90.42 and $93.04 \%$, respectively) as compared to the infected group. On the other hand, mice vaccinated with non-irradiated antigen showed non remarkable reduction in ova count in liver (17.68\%) as compared to infected group (Table 3). In intestine, the percentage of resistance in mice vaccinated with irradiated antigen or treated with PZQ reached 87.89 and $88.15 \%$ respectively as compared to the infected group. While the percentage of resistance in mice vaccinated with non-irradiated antigen was lower than the other groups $(23.46 \%)$ (Table 3$)$.

The data obtained in table (4) indicated that PZQ treatment induced reduction in male \& female worms accompanied with a significant reduction in couple worms reached 24.19, 14.16 and $81.26 \%$, respectively as compared to infected group, whereas the immunization with $\gamma$-irradiated antigen caused a reduction in male worms $(25.54 \%)$ paralleled with an increase in female worms $(21.46 \%)$. It also revealed a significant reduction $(70.01 \%)$ in couple worms as compared to infected group. In addition, mice immunized with non-irradiated antigen induced approximately the same trend of percentage of resistance as mice immunized with $\gamma$ irradiated antigen. It is worthy to mention that the percentage of increase in female worms was more pronounced $(64.38 \%)$ as compared to the infected group.

\section{3- Immunological analysis}

The data showed in table (5) that serum TNF- $\alpha$ in infected group was highly significantly decreased $(\mathrm{P}<0.01)$. Such decrease reached $33.05 \%$ as compared with control. Treatment with PZQ or immunization with irradiated antigen also induced significant decrease in serum TNF- $\alpha$. Whereas, the lowest decrease was recorded in mice immunized with non-irradiated antigen. 
The infected group exhibited highly significant increase in serum IL-10 level (723.96 \%) as compared with control (Table 5). While, in the groups either treated with PZQ or immunized with non- irradiated antigen showed highly significant increase in serum IL-10 as compared with control. However, irradiated antigen produced a significant decrease in this level comparing with infected group.

Table (1): Effect of immunization with $\gamma$-irradiated and non-irradiated schistosomula antigen and PZQ treatment on serum $\gamma$-GT and alkaline phosphatase in mice infected with alive $S$. mansoni cercariae.

\begin{tabular}{|c|c|c|c|c|c|}
\hline Groups & Control & Infected & PZQ & $\begin{array}{c}\text { Irrad. antigen } \\
(\mathbf{2 0} \text { Krad) }\end{array}$ & $\begin{array}{c}\text { Non-irrad. } \\
\text { antigen }\end{array}$ \\
\hline $\begin{array}{c}\gamma \text {-GT (U/ L) } \\
\text { Mean } \pm \text { SE }\end{array}$ & $5.22 \pm 0.44$ & $8.42 \pm 0.21$ & $6.77 \pm 0.31$ & $5.43 \pm 0.34$ & $10.3 \pm 0.33$ \\
\hline \% Change & 100 & 161.3 & 129.69 & 104.02 & 197.32 \\
\hline P & --- & $<0.001$ & $<0.05$ & n.s. & $<0.001$ \\
\hline $\begin{array}{c}\text { Alk-phosph (U/L) } \\
\text { Mean } \pm \text { SE }\end{array}$ & $126.2 \pm 2.29$ & $193.53 \pm 2.46$ & $295.6 \pm 2.43$ & $210.54 \pm 2.09$ & $294.17 \pm 3.29$ \\
\hline \% Change & 100 & 153.35 & 234.24 & 166.83 & 233.09 \\
\hline P & --- & $<0.001$ & $<0.001$ & $<0.001$ & $<0.001$ \\
\hline
\end{tabular}

$\mathrm{P}<0.05$ Significant from control group.

$\mathrm{P}<0.001$ highly significant from control group.

N.S. Non significant from control group.

Table (2): Effect of immunization with $\gamma$-irradiated and non-irradiated schistosomula antigen and PZQ treatment on serum ALT and AST in mice infected with alive $S$. mansoni cercariae.

\begin{tabular}{|c|c|c|c|c|c|}
\hline Groups & Control & Infected & PZQ & $\begin{array}{c}\text { Irrad. antigen } \\
\text { (20 Krad) }\end{array}$ & $\begin{array}{c}\text { Non-irrad. } \\
\text { antigen }\end{array}$ \\
\hline $\begin{array}{c}\text { ALT(U / L) } \\
\text { Mean } \pm \text { SE }\end{array}$ & $23.2 \pm 0.23$ & $64.7 \pm 2.26$ & $41.62 \pm 1.605$ & $42.33 \pm 1.59$ & $53.64 \pm 2.06$ \\
\hline \% change & 100 & 278.88 & 179.39 & 182.46 & 231.21 \\
\hline P & --- & $<0.001$ & $<0.001$ & $<0.001$ & $<0.001$ \\
\hline $\begin{array}{c}\text { AST (U / L) } \\
\text { Mean } \pm \text { SE }\end{array}$ & $14.6 \pm 0.12$ & $54.14 \pm 1.87$ & $40.72 \pm 1.28$ & $46.078 \pm 1.68$ & $60.48 \pm 1.84$ \\
\hline \% change & 100 & 370.82 & 278.90 & 315.60 & 414.25 \\
\hline P & -- & $<0001$ & $<0.001$ & $<0.001$ & $<0.001$ \\
\hline
\end{tabular}


Table (3): Effect of immunization with $\gamma$-irradiated and non-irradiated schistosomula antigen and PZQ treatment on ova count / gm liver and gm intestine in mice infected with alive $S$. mansoni cercariae.

\begin{tabular}{|l|c|c|c|c|}
\hline Groups & Infected & PZQ & $\begin{array}{c}\text { Irrad. antigen } \\
\text { (20 Krad) }\end{array}$ & $\begin{array}{c}\text { Non-irrad. } \\
\text { antigen }\end{array}$ \\
\hline $\begin{array}{l}\text { Ova count /gm. liver } \\
\text { Mean } \pm \text { SE }\end{array}$ & $4024.17 \pm 35.98$ & $280.0 \pm 3.0$ & $385.6 \pm 03.64$ & $3312.71 \pm 273.83$ \\
\hline P & --- & $<0.001$ & $<0.001$ & $<0.001$ \\
\hline \% resistance & --- & 93.04 & 90.24 & 17.68 \\
\hline $\begin{array}{l}\text { Ova count/g. intestine } \\
\text { Mean } \pm \text { SE }\end{array}$ & $2750.45 \pm 238.86$ & $326.0 \pm 99.0$ & $333.2 \pm 99.3$ & $2105.29 \pm 321.71$ \\
\hline P & --- & $<0.001$ & $<0.001$ & $<0.05$ \\
\hline \% resistance & --- & 88.15 & 87.89 & 23.46 \\
\hline
\end{tabular}

Table (4): Effect of immunization with $\gamma$-irradiated and non-irradiated schistosomula antigen and PZQ treatment on worm burden in mice infected with alive $S$. mansoni cercariae.

\begin{tabular}{|c|c|c|c|c|c|c|c|c|c|c|c|c|}
\hline Groups & \multicolumn{3}{|c|}{ Infected } & \multicolumn{3}{|c|}{$\mathbf{P Z Q}$} & \multicolumn{3}{|c|}{$\begin{array}{c}\text { Irrad .antigen (20 } \\
\text { krad) }\end{array}$} & \multicolumn{3}{|c|}{ Non-irrad. antigen } \\
\hline & $\sigma^{\lambda}$ & q & $+0^{\lambda}$ & $\hat{0}$ & 우 & $+0^{\lambda}$ & $0^{\lambda}$ & o & $+0^{\lambda}$ & $\hat{0}$ & q & $+\hat{0}$ \\
\hline $\mathbf{M e}$ & $\begin{array}{c}9.67 \\
\pm \\
3.18\end{array}$ & $\begin{array}{c}2.33 \\
\pm \\
0.67\end{array}$ & $\begin{array}{c}6.67 \\
\pm \\
2.19\end{array}$ & $\begin{array}{c}7.33 \\
\pm \\
2.73\end{array}$ & $\begin{array}{c}2.0 \\
\pm \\
0.1\end{array}$ & $\begin{array}{c}1.25 \\
\pm \\
0.25\end{array}$ & $\begin{array}{c}7.2 \\
\pm \\
169\end{array}$ & $\begin{array}{c}2.83 \\
\pm \\
\pm \\
1.45\end{array}$ & $\begin{array}{c}2.00 \\
\pm \\
0.49\end{array}$ & $\begin{array}{c}7.00 \\
\pm \\
157\end{array}$ & $\begin{array}{c}3.83 \\
\pm \\
101\end{array}$ & $\begin{array}{c}1.25 \\
\pm \\
0.25\end{array}$ \\
\hline $\begin{array}{l}\% \\
\text { resistan }\end{array}$ & --- & --- & - & 24.19 & 14.16 & 81.26 & 25.54 & 21.46 & 70.01 & 27.61 & 64.38 & 81.26 \\
\hline
\end{tabular}

Table (5): Effect of immunization with $\gamma$-irradiated and non-irradiated schistosomula antigen and PZQ treatment on serum tumor necrosis factor TNF- $\alpha$ and interlukin 10 (IL-10) in mice infected with $S$. mansoni cercariae.

\begin{tabular}{|c|c|c|c|c|c|}
\hline Groups & Control & Infected & PZQ & $\begin{array}{c}\text { Irrad. antigen } \\
(\mathbf{2 0} \text { Krad) }\end{array}$ & $\begin{array}{c}\text { Non-irrad. } \\
\text { antigen }\end{array}$ \\
\hline $\begin{array}{c}\text { TNF- } \boldsymbol{\alpha} \\
\text { Mean } \pm \text { SE }\end{array}$ & $66.00 \pm 0.580$ & $21.805 \pm 0.581$ & $34.165 \pm 0.581$ & $31.805 \pm 0.571$ & $54.317 \pm 0.579$ \\
\hline \%Change & 100 & 33.05 & 51.77 & 48.19 & 82.30 \\
\hline P & & $<0.01$ & $<0.01$ & $<0.01$ & $<0.01$ \\
\hline $\begin{array}{c}\text { IL-10 } \\
\text { Mean } \pm \text { SE }\end{array}$ & $86.363 \pm 0.593$ & $711.937 \pm 4.28$ & $415.085 \pm 2.367$ & $224.895 \pm 4.848$ & $485.960 \pm 5.241$ \\
\hline \%Change & 100 & 823.96 & 480.64 & 260.42 & 562.71 \\
\hline P & & $<0.001$ & $<0.001$ & $<0.001$ & $<0.001$ \\
\hline
\end{tabular}

\section{4- Scanning electron microscopy}

Figures $(1 \& 2)$ show scanning electron microscopy of normal adult worms recovered from infected mice after 45 days of infection with alive $S$. mansoni cercariae

Figures (3A-D) represent scanning electron microscopy of adult worms collected from infected mice immunized with non-irradiated schistosomula antigen.
A number of changes have been observed in these worms including: wide abnormal gynacoventral groove (Fig.3 A), deformation in the anterior sucker (Fig.3 B), shortage and shrinkage of the whole worm (Fig.3 C) as well as severe loss of the spines from the tubercles and most of the spines on the tegumental surface were detached (Fig. 3D). 
Figures (4A-D) show the scanning electron microscopy of worms recovered from infected mice immunized with irradiated antigen after 45 days of infection with alive $S$. mansoni cercariae. Fig. (4A) shows a severe deformation of gynacoventral groove together with swelling and erosion in one side of groove. While, Figs. (4B and C) illustrate a dramatic deformation in the whole worm which appeared like a roll with a very wide groove twisted to the outer side. Also, intensive disruption in the tegumental surface was observed as shown in Fig.(4 D) with severe loss of spines from the tubercles .

Figures (5A-D) show scanning electron microscopy of $S$. mansoni worms recovered from infected mice treated with PZQ after 45 days of infection. A variety of

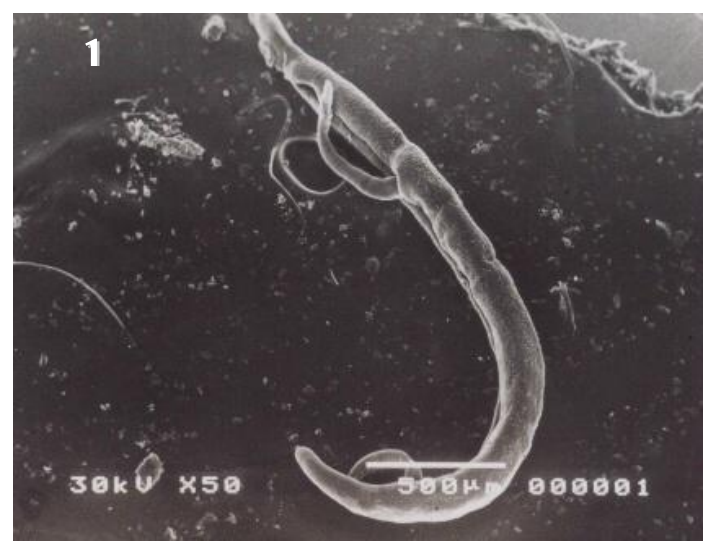

changes have been observed post PZQtreatment in adult worms. A characteristic deformation in gynaecoventral canal (Fig.5A) accompanied with shortage and shrinkage of male worm (Fig. 5B) Severe degree of surface tegumental disruption and increased loss or complete loss of spines were observed and the surface was sloughed off (Fig. 5 C). The tegumental alterations induced by PZQ were progressed to implosion of tubercles which appeared pealed and sloughed off and most of the spines were detached and separated (Fig.5D).

Figures (6A \& B) show the spine which is separated from the group of infected mice immunized with antigens or treated with praziquantel, the spine is pointed and detatched from its base.

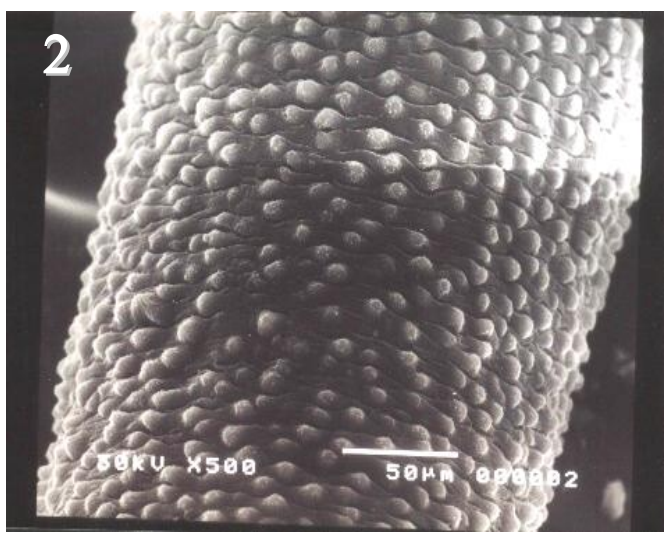

Figs (1\&2) Scanning electron microscopy of normal adult couple (male \& female) $S$. mansoni worms collected from infected mice. 

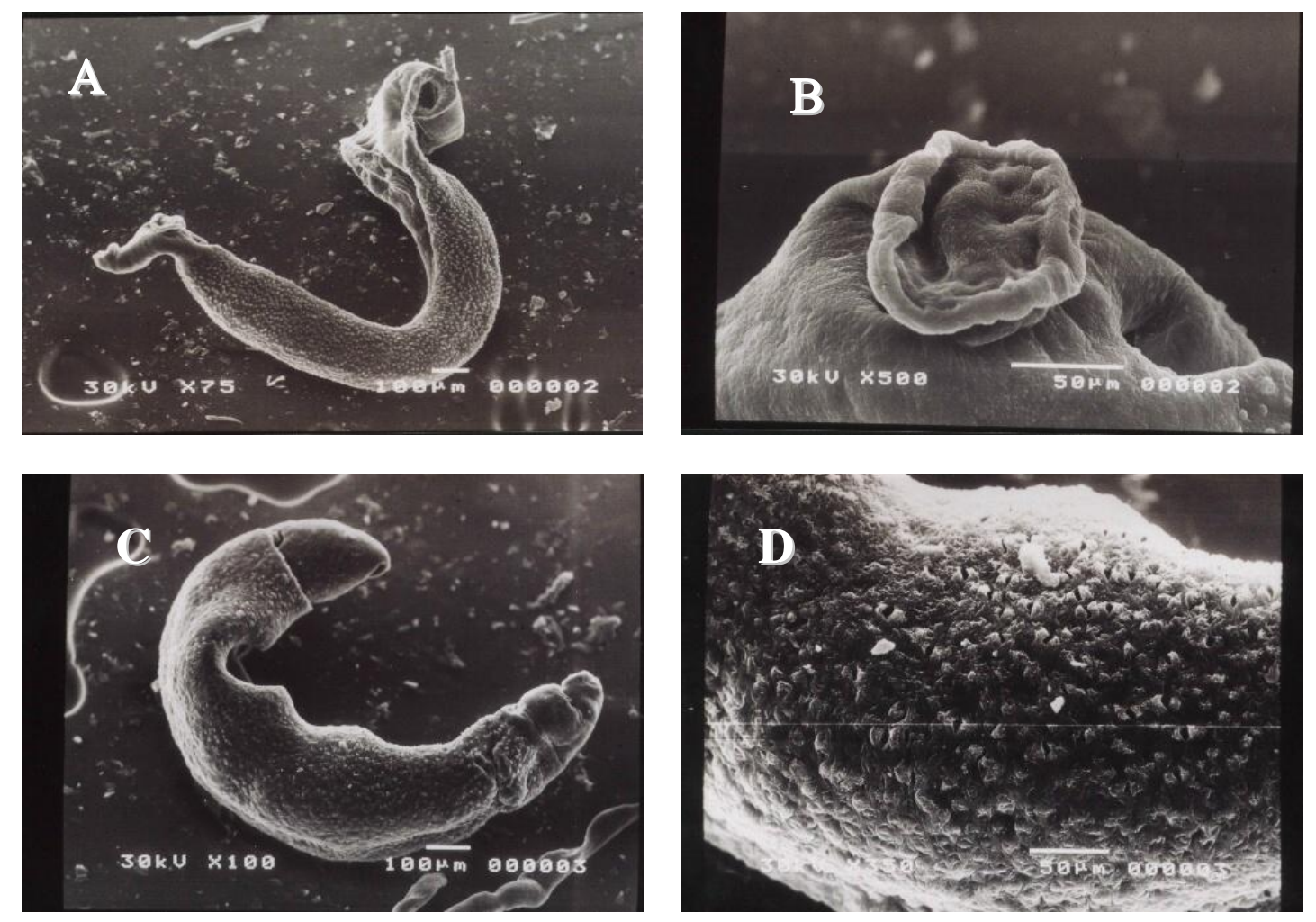

Figs (3A, B, C \& D): Scanning electron microscopy of male $S$. mansoni worms recovered from infected mice immunized with non-irradiated schistosomula antigen
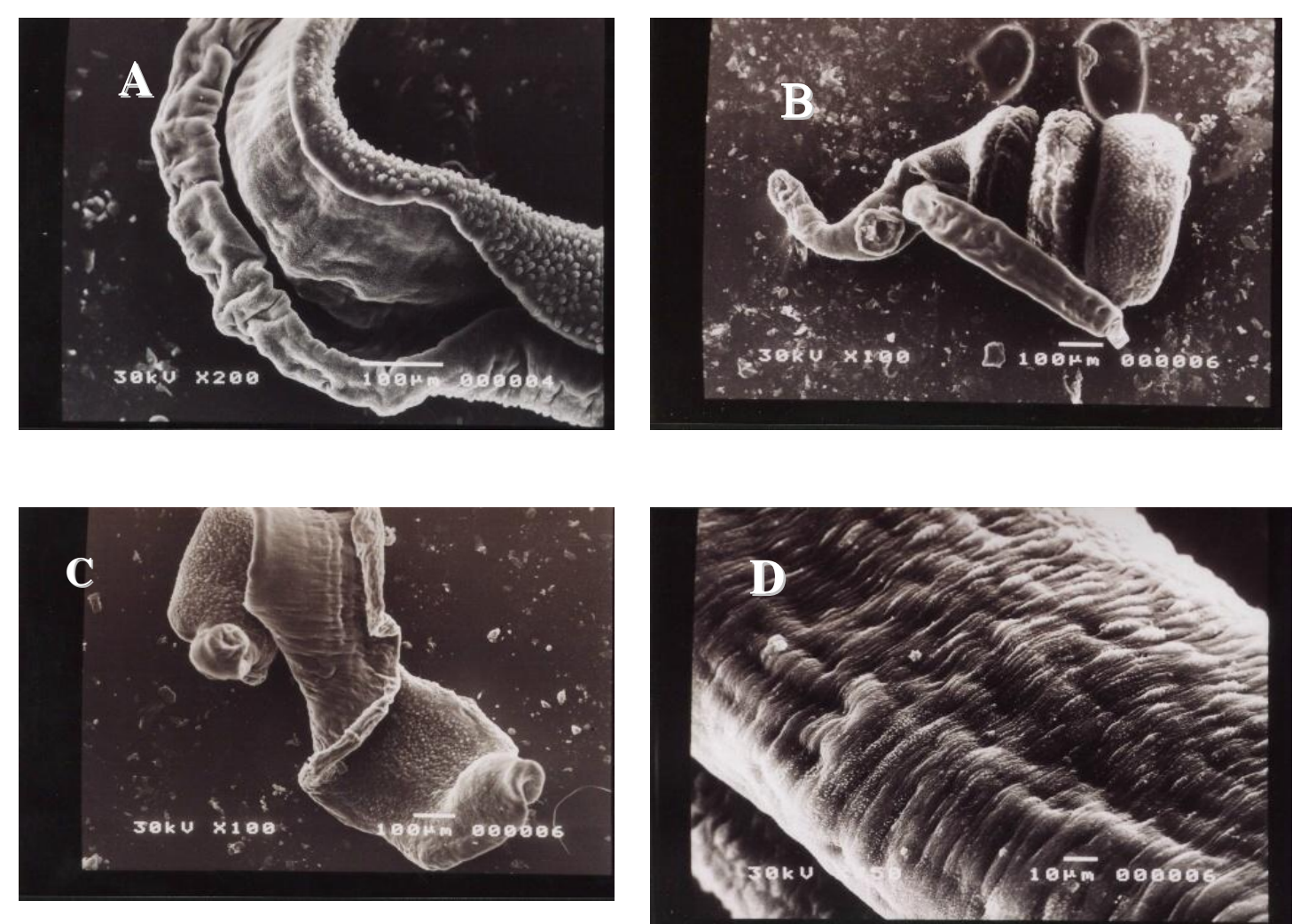

Figs (4A, B, C \& D): Scanning electron microscopy of $S$. mansoni worms recovered from infected mice immunized with irradiated schistosomula antigen. 

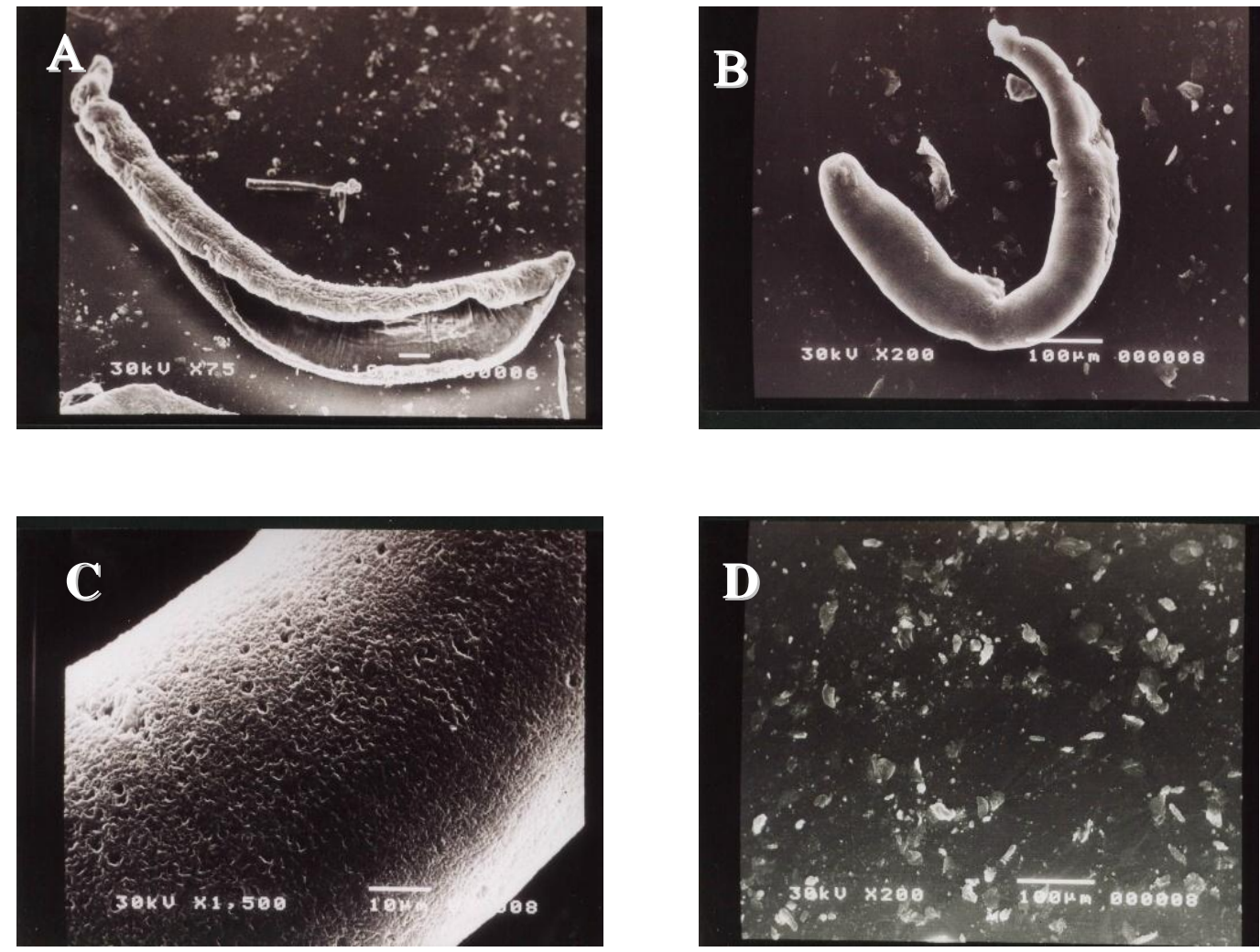

Figs (5A, B, C \& D): Scanning electron microscopy of S. mansoni worms recovered from infected mice treated with praziquantel.
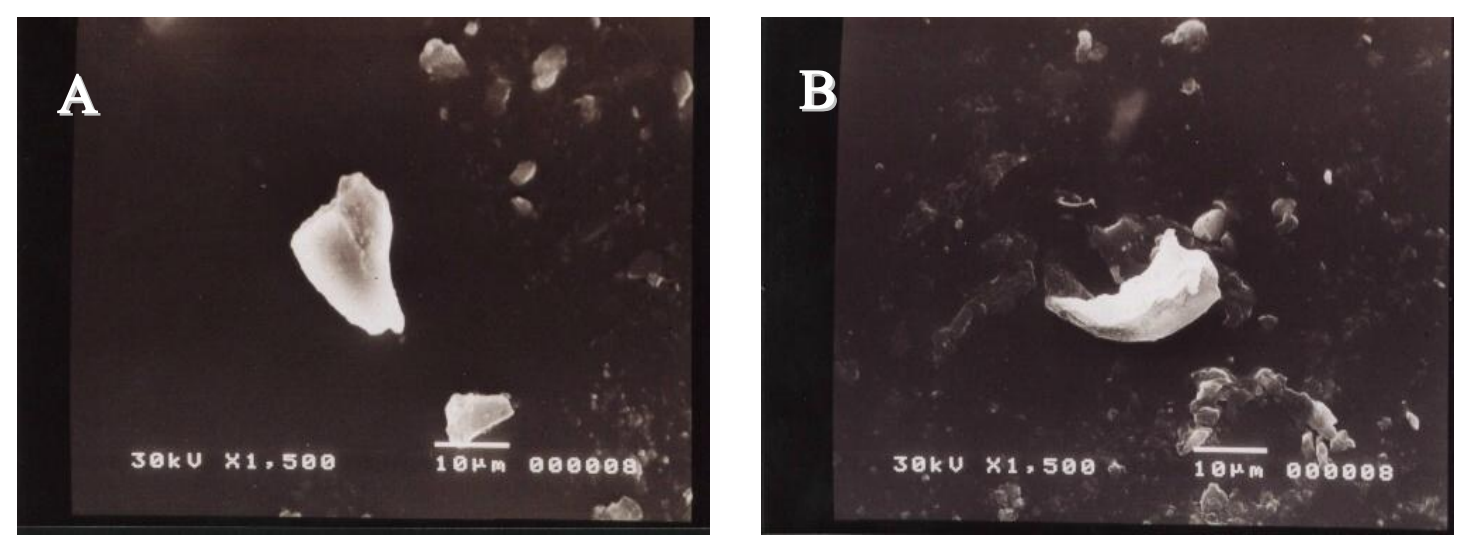

Figs (6 A \& B): Scanning electron microscopy of spines separated from infected mice preimmunized with antigens or treated with praziquantel.

\section{5- Histopathological observations}

A-Liver

-Control group: The normal architecture of mouse liver is illustrated in Fig. (7).

-Infected group: Livers of infected mice with alive S.mansoni cercariae showed highly dilated and congested hepatic portal veins which lodged with adult worms. The portal tract showed periportal fibrosis, bile duct proliferation and severe cellular infiltration. Hyalinosis in the wall of blood vessel was also marked. Moreover, localized masses of parenchymal cellular infiltration were also seen forming small and large granuloma composed of lymphocytes, 
histocytes and plasma cells. Besides, cloudy swelling in hepatocytes and occurrence of necrotic foci were observed. Close to the necrotic areas, the blood sinusoids were ruptured and congested with hypertrophied kupffer cells and extravasated blood (Figs. 8A, B, C, D \& E).

-Praziquantel (PZQ) treated group: Liver sections taken from mice treated with PZQ after infection showed highly affected portal area. Some portal veins contained contracted adult worms and surrounded by cellular infiltrates. The liver cells sometimes showed specific changes such as pleomorphism of cells or nuclei. Swollen vacuolated cells with pyknotic and karyolytic nuclei were obviously seen. There are also focal necrotic areas and diffused interstitial infiltrates. However, an improvement could be seen in some liver sections, where a relatively normal appearance of hepatocytes was noted. There was little damage to the liver parenchyma and portal tracts as represented by less cellular infiltration as well as reduction in granulomas size (Figs. 9A, B, \& C).

\section{-Immunized group with non-irradiated} schistosomula antigen: Livers of mice immunized with non-irradiated antigen before infection showed dilated portal vein with ruptured endothelial lining and periportal cellular infiltration. Adult worms with vacuolated and disrupted tegument were observed inside veins. In addition, liver parenchyma showed markedly enlarged hepatocytes, fatty degeneration together with moderate and relatively small interstitial lymphocytic aggregations. Moreover, large fibrous granulomas, dilated sinusoidal spaces and cell necrosis were also well marked (Figs. $10 \mathrm{~A}, \mathrm{~B} \& \mathrm{C}$ ).

\section{-Immunized group with irradiated} schistosomula antigen: Immunization of mice with irradiated antigen prior to infection with alive S.mansoni cercariae greatly minimized the pathogenesis observed in liver as compared to that in infected mice and not immunized. An almost normal hepatic appearance was seen with marked evidence of regeneration and mitotic activity. Additionally, little periportal cellular infiltrates without granuloma formation and with less collagen deposition were also detected (Figs. 11 A \& B).

\section{B-Lung}

-Control group: The normal mouse lung is shown in Fig. (12).

-Infected group: Lung of infected mice with alive S.mansoni cercariae showed partial destruction of bronchiolar wall with mononuclear cellular invasion. Compact aggregates of mixed inflammatory cells were present within the interstitial tissue. Aggregations of lymphocytes were also seen around blood vessels what is called "lymphocytic cuffing". Furthermore, disruption of alveolar walls was detected, some showed sloughing into alveolar spaces. However, thickened interalveolar septa with inflammatory cells and congested capillaries were noticed. There are also markedly engorged blood vessels and focal heamorrhagic areas (Figs. 13 A, B \& C).

-Praziquantel (PZQ) treated group: The histological picture of the lungs of mice treated with PZQ was characterized by the presence of peribronchiolar fibrosis and cellular infiltration. Pulmonary lesions also included granulomatosis reaction. Moreover, swelling and vacuolar degeneration of the epithelial lining of the bronchioles were also seen. Some interalveolar septae were thickened by mixed cellular infiltration, enlarged foamy cells and extravasated RBCs. Also, some alveoli contained exudate in their luminae. However, besides these lesions, an almost normal appearance of alveoli and bronchioles could also be seen (Figs. 14 A, B \& C).

-Immunized group with non-irradiated shistosomula antigen: Lung of mice immunized with non-irradiated antigen 
showed interstitial peribronchiolar and perivascular fibrosis. Ruptured bronchiolar walls with cellular infiltration of bronchiolar epithelium were seen. Moreover, intrabronchiolar exudate was noticed. Lungs also showed increased signs of pneumocytes infiltration which obstructed alveolar sacs. In addition, there are some alveoli with shed destroyed epithelium and extravasated RBCs (Figs. 15 A \& B).
-Immunized group with irradiated schistosomula antigen: Lung sections taken from mice immunized with irradiated antigen revealed that most of the alveoli and bronchioles retained their normal pattern. This case reflects the occurrence of an obvious amelioration, where an almost normal thickness of interalveolar septa was obtained as well as many bronchioles appeared healthy. However, mild pulmonary congestion, cellular infiltration and focal emphysematous areas were still present (Fig. 16). 

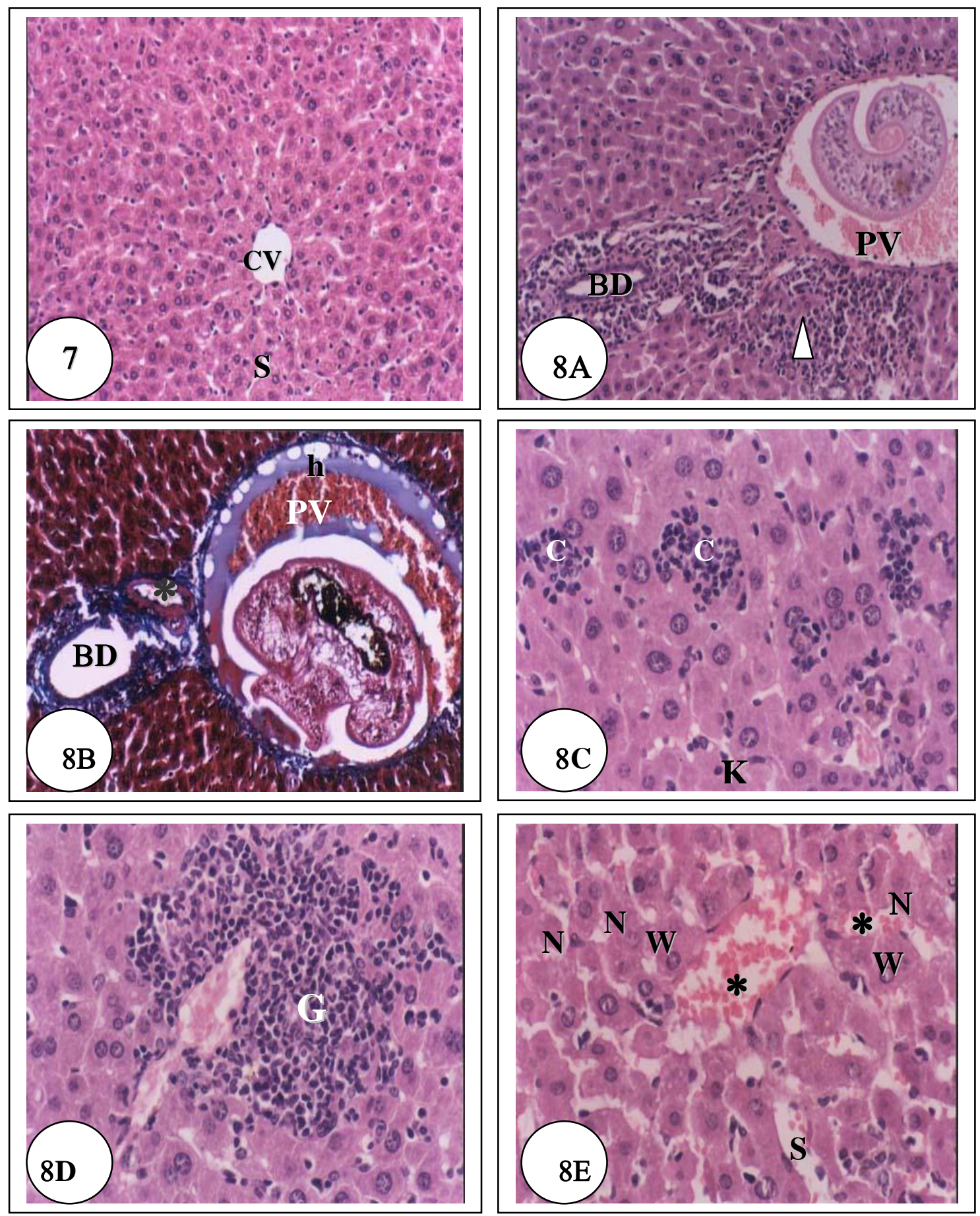

Fig.7: Section in liver of a control mouse showing central vein (CV)and cords of hepatocytes radiating from it and separated from each other by blood sinusoids (S) (H \& E, X 200).

Figs. (8A, B, C, D \& E): Sections in liver of mice infected with alive S.mansoni cercariae showing:

A) Thickening, dilatation and congestion of hepatic portal vein $(\mathrm{PV})$ which is loaded with adult worm. Note periportal cellular infiltration ( ) and bile duct proliferation (BD) (H \& E, X 200).

B) Engorged portal vein (PV) with adult worm inside it. Note hyalinosis (h) in the wall of portal vein, thickening of hepatic artery $(*)$ and bile duct proliferation (BD) (Masson's trichrome, $\mathrm{X}$ 200).

C) Focal parenchymal cellular infiltration giving picture of granuloma $(\mathrm{G})$ (small sized granulomas with irregular outlines) and hyperophied Kupffer cells (K) (H \& E, X 400).

D) Large granuloma formation (G) (H \& E, X 400).

E) Dilated blood sinusoids (S) with inflammatory cells and haemorrhagic infiltrations (*). Note cloudy swelling (W) in hepatocytes and focal necrosis (N) (H \& E, X 400) 

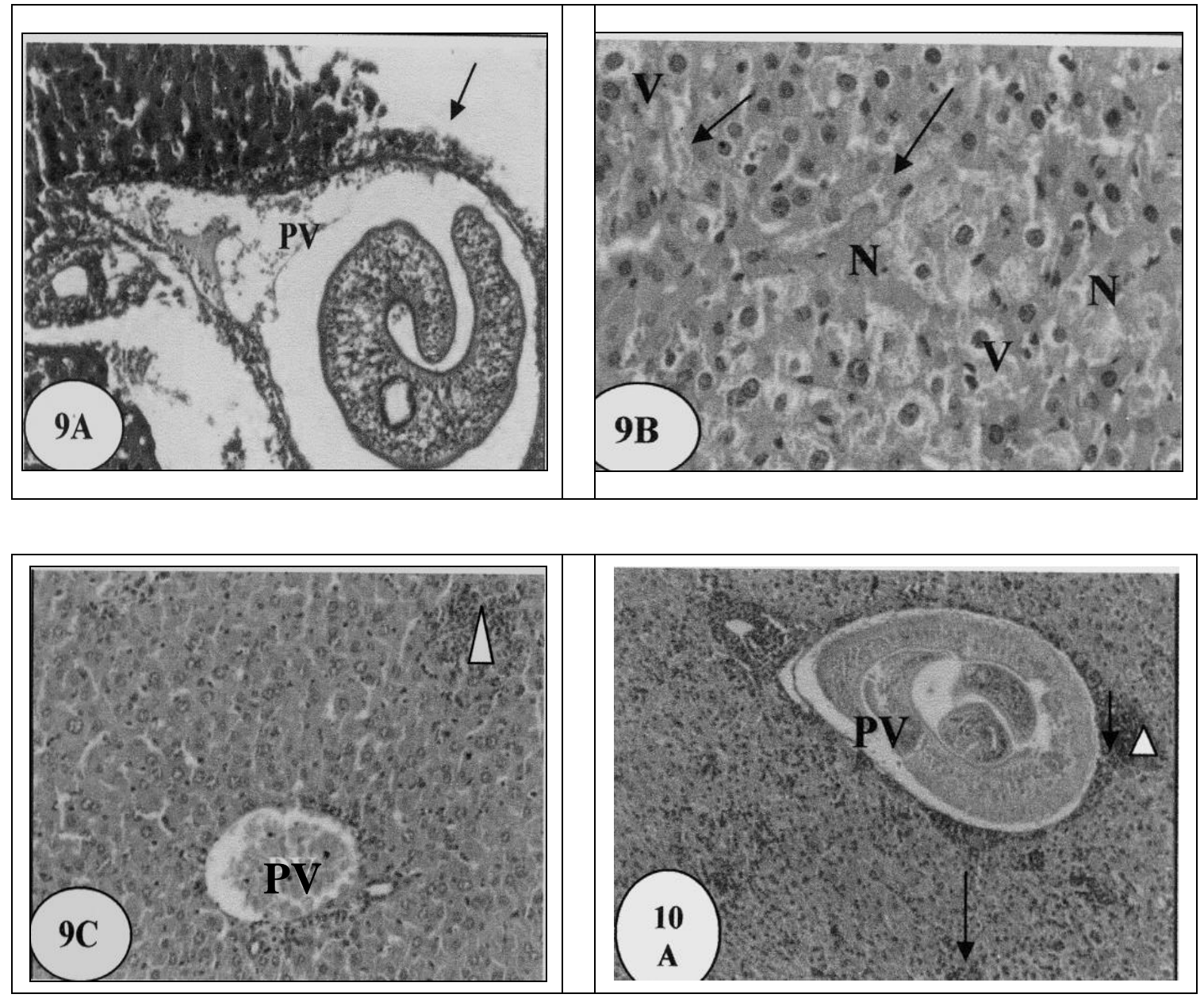

Figs. (9A, B \& C): Sections in liver of mice treated with PZQ showing:

A) Dilated portal vein (PV) with ruptured and inflamed vascular endothelium. Note adult worm with irregular tegument inside the portal vein, periportal cellular infiltration $(\rightarrow)$ and destructed liver cells bounded to portal zone (Massons trichrome, X 200).

B) Swelling and vacuolar degeneration of the majority of hepatocytes (V). Note focal necrotic areas $(\mathrm{N})$ and extravasated RBCs $(\rightarrow)$ within sinusoidal spaces (H \& E, X 400).

C) Congested hepatic portal vein (PV) with minimal cellular infiltrates. Note relatively normal appearance of hepatic cells with interstitial granuloma of infiltrating cells ( ) (H \& E, X 200).

Figs. (10A, B \& C): Sections in liver of mice immunized with non-irradiated antigen showing:

A) Adult worm with disrupted and vacuolated tegument inside the portal vein (PV). Note periportal granuloma $(\longrightarrow)$ as well as diffused parenchymal cellular infiltration $(\rightarrow)$ (H \& E, X 200). 


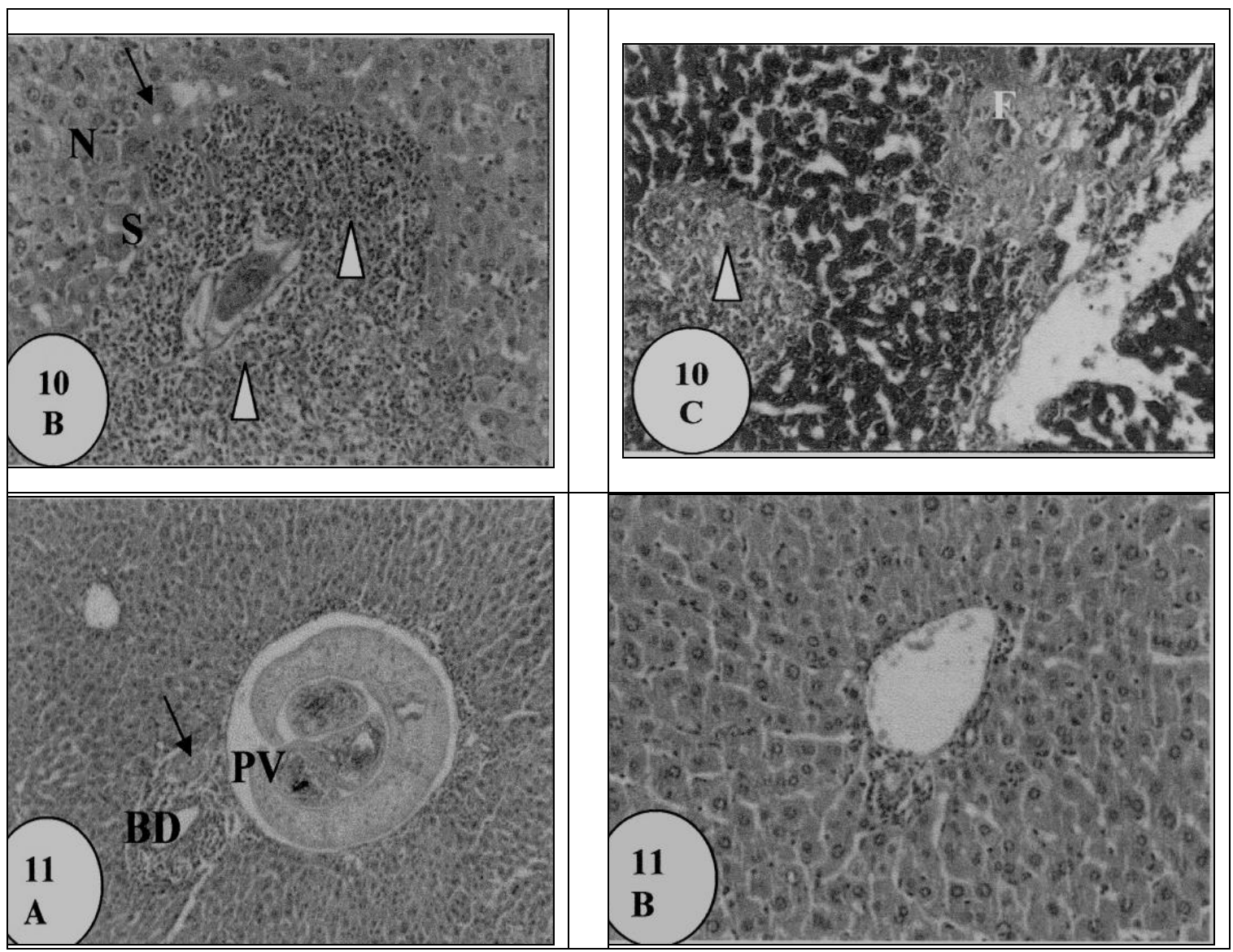

B) Large granuloma $(\downarrow)$ centered by S.mansoni ova. Note sinusoidal dilatation (S), cell necrosis $(\mathrm{N})$ and small fat droplets $(\rightarrow)(\mathrm{H} \& \mathrm{E}, \mathrm{X} 200)$.

C) Dilated congested blood vessel and sinusoidal spaces. Note severe and large granuloma with ( $\$$ ) fibrous tissue invasion (F) (Masson's trichrome, X 200).

Figs. (11A \&B): Sections in liver of mice immunized with irradiated antigen showing:

A) Adult worm with disrupted and vacuolated tegument deposited in the portal vein (PV). Note thickened artery $(\rightarrow)$ and proliferated bile duct $(\mathrm{BD})$, however the hepatic architecture appeared otherwise normal (H \& E, X 200).

B) Relatively normal appearance of hepatocytes and portal area without granuloma formation (H \& E, X 200). 



Fig. 12: Section in lung of a control mouse showing normal alveoli, interalveolar septa and a bronchiole (b) (H \& E, X 200).

Figs. (13 A, B \& C): Sections in lung of mice infected with alive S.mansoni cercariae showing:

A) Partial destruction of bronchiolar (b) wall with lymphocytic infiltration of bronchiolar epithelium. Note thickened alveolar $(*)$ and arterial (a) walls with compact mass of cellular infiltration $(\nabla)(\mathrm{H} \& \mathrm{E}, \mathrm{X} 200)$.

B) Peribronchiolar and perivascular fibrosis (Masson's trichrome, X 200).

C) Thickening of alveolar walls, some show sloughing $(*)$ into alveolar spaces. Note engorged blood vessel (BV) with perivascular cellular infiltration (H \& E, X 200). 

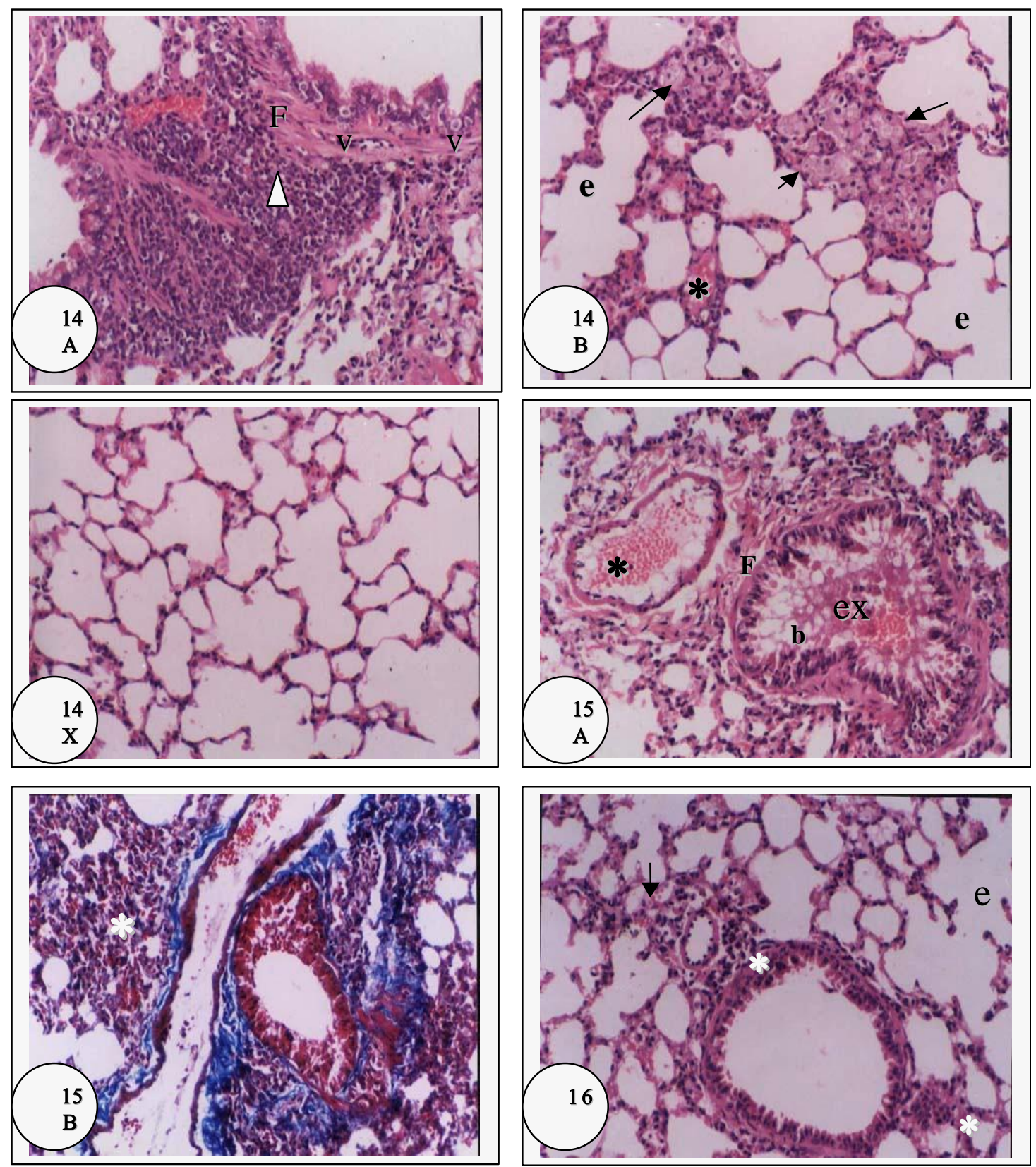

Figs. (14 A, B \& C): Sections in lung of mice treated with PZQ showing:

A) Fibrous thickening $(\mathrm{F})$ of bronchiole with vacuolar degeneration $(\mathrm{V})$ of epithelial lining. Note intense peribronchiolar cellular infiltration ( $)$ with haemorrhagic and fibroblastic invasions (H \& E, X 200).

B) Thickening of interalveolar septa $(\rightarrow)$ by enlarged foamy cells and extravasated RBCs $(*)$. Note compensatory emphysema (e) (H \& E, X 200).

C) An almost normal thickeness of interalveolar septa (H \& E, X 200).

Figs. (15 A \& B): Sections in lung of mice immunized with non-irradiated antigen showing:

A) Peribronchiolar and perivascular fibrosis (F) besides ruptured bronchiolar (b) wall with invasion by inflammatory cells. Note intrabronchiolar exudation (ex) and congested artery (*) (H \& E, X 200).

B) Interstitial peribronchiolar and perivascular fibrosis. Note dilated congested blood vessel and thickened interalveolar septa with increased signs of pneumocytes infiltration $(*)$ which obstructed alveolar sacs (Masson's trichrome, X 200).

Fig. 16: Section in lung of mice immunized with irradiated antigen showing relatively normal appearance of alveoli, bronchiole and artery. Note mild cellular infiltration $(*)$, pulmonary congestion $(\rightarrow)$ and signs of emphysema (e) (H \& E, X 200). 


\section{Discussion}

Schistosomiasis, a grave and debilitating disease of socioeconomic impact, is increasing in incidence despite concentrated efforts to control the disease in all endemic areas. Many complications happened along years of infection, with resultant progressive destruction for many tissues allover the body such as fibrosis of the liver and failure of its function which leads to disability and even death of the patient. Chemotherapy plays a role in preventing the transmission of the disease and vaccination is still a dream against that parasite.

The data of the present study revealed a highly significant reduction of ova count in both liver and intestine in the groups of infected mice treated with PZQ or vaccinated with irradiated antigen more than the non-irradiated antigen compared to infected group. It is well known that schistosomula are covered with complex carbohydrate network which constitutes the glycocalyx surrounding the parasite tegument. This carbohydrate network interferes with the development of high degree of resistance (Wales et al., 1993). Such reduction was not observed in case of mice immunized with non-irradiated schistosomula antigen. These results are in agreement with Menson et al. (1989) and Wyan et al. (1994). It has been reported that exposure to gamma-irradiation at 20 krad could induce a pronounced modification of the complex carbohydrate network, which constitutes the glycocalyx, expressed at the surface of schistosomula. Gamma-irradiation seems to induce degrading changes in carbohydrate polymers that could make antigenic determinants in glycocalyx itself more accessible to antibody binding, or may expose epitopes normally hidden in the underlying membrane (Wales et al.,1993 and Mountford et al., 1995).

It is worthy to mention that, the present work was a trial to apply the optimum condition in order to augement the level of resistance against infection with alive $S$. mansoni cercariae. Among the major conditions for choice are the irradiation dose level, dose of immunized antigen and number of injected dose. Lewis et al. (1984) reported that the effectiveness of irradiated schistosomula antigen to induce protection was lost in those receiving radiation dose more than $20 \mathrm{krad}$. They added that protection induced by $40-$ $50 \mathrm{krad}$ irradiated schistosomula was relatively low and highly variable.

As a result, new antigenic determinates could be presented to helper $\mathrm{T}$-lymphocytes and therefore stimulating potent protective immunity. The low level of resistance in mice vaccinated with nonirradiated antigen assessed by ova count increment may be due to shedding of surface antigens explaining the reduced surface antigenicity of the parasite (Pearce et al., 1986).

On the other hand, the presence of abnormal and often sterile adult worms in the liver of mice vaccinated with irradiated antigen may explain the reduction of ova or ovideposition. Consequently, the notable difference between immunization of mice with irradiated or non-irradiated antigen in ova count accompanied with similar percentage of worm burden which may be attributed to the fecundity of worms and hence a difference in egg production. The data obtained demonstrated that the numbers of male worms and copula in the immunized groups as well as groups of mice treated with PZQ were lower than those in the infected group. Some investigators have pointed to the early days of infection as a most hopeful of attack. During this time the parasite had no time to deploy its various tricks, and could be vulnerable to antibodies primed by vaccine based on the surface antigens from this early stage schistosomula (Menson et al., 1989).

In accordance with many previous observations, mice infected with alive $S$. mansoni cercariae exhibited an impairment of the hepatic function as 


\section{Mona A. El-Gawish et al}

reflected by a significant increase in serum $\gamma$-GT, alkaline phosphatase, ALT and AST. The present physiological parameters are considered as markers for hepatocellular injury with severe periportal fibrosis. The significant elevation of these parameters may reflect early liver tissue damage from egg secreted proteases due to the great number of egg deposition occurred after infection (Ashton et al., 2001). The increase in serum ALT was reported to be specific for necrosis and liver damage (El-Shaikh et al., 1998). The changes in transaminases may be also attributed to release of enzymes from damaged hepatic cells into the blood stream as well as the existence of inflammatory hepatic granuloma, as a result of egg deposition and presence of worms and their toxins (El-Haieg et al., 1997). Additionally, the increase in serum alkaline phosphatase is considered as a marker for biliary obstruction and for general liver pathology. In contrast, immunization with non-irradiated antigen induced no signs of amelioration in the mentioned parameters. These data may support the beneficial and protective effects of irradiated antigen than non-irradiated one, since exposure to $\gamma$-rays interferes with development of high degree of resistance.

The present data recoded a significant increase in IL-10 paralleled with a significant decrease in TNF- $\alpha$ in groups immunized with schistosomula antigen or treated with PZQ in comparison with infected group. These results are in agreement with those of Hoffmann et al. (1998) and Silveira et al. (2004). Circulating worm antigen likely constitutes a stimulus for inflammatory cells to secrete larger amounts of chemokines with proinflammatory action, increasing and accelerating granuloma cellularity. Leptak and Mckerrow (1997) showed that hepatic expression of TNF- $\alpha$ as proinfammatory cytokine and schistosome egg granuloma formation is dependent on immune priming by adult $S$. mansoni worms prior to egg deposition and that hepatic expression of TNF- $\alpha$ is a reaction to adult worms, but not eggs.
Activated macrophages can secrete many cytotoxic mediators that are responsible for parasite death via diffusion into schistosomulum across the surface tegument (Pearce and James, 1986). TNF- $\alpha$ was mainly produced by monocytes and activated macrophages. Hence TNF- $\alpha$ could participate in inflammatory activities, and cell toxicity increasing $\mathrm{Nk}$ function, as well as its protective effects against immunopathology in the early stage of infection (Hoffmann et al., 1998). The authors reported that TNF- $\alpha$ declined at the time of egg laying developed granuloma. Davies et al. (2004) demonstrated that signalling by TNF and its receptors can influence granuloma formation and limit hepatoc-ellular damage in response to schistosome eggs.

It has been reported that the balance between Th1 and Th2 cytokines level could be modulated to help reverse or decrease fibrosis in $S$. mansoni infected hamesters and treated with PZQ (Helmy et al., 2005). Infection with irradiated antigen stimulated a marked inflammatory response in the skin, resulting in delaying migration of the parasite through the skin (Ramaswamy et al., 2000). The role of $\mathrm{IL}-10$ in the suppression of Th1 cytokine synthesis (IFN- $\gamma$, IL-2 ) in murine and human has been reported by Montenegro et al. (1999). Alonso et al. (2006) also found a potential associations of the level of fibrosis, intensity of infection and cytokine production of IL-10. In addition, IL-10 is a crucial agent in the down-modulation of immune response and immunopathology that defines the transition from acute to chronic disease, since IL-10 regulates not only the intensity of hepatic inflammation, but also granuloma organization and cohesiveness (Sadler et al., 2003).

Scanning electron microscopy (SEM) is considered as a useful tool for the study of the structure of the outer surface of many helminthes, particularly schistosomes. In the present study, the SEM has provided dramatic illustration of the external appearance of adult $S$. mansoni recovered from immunized mice (irradiated or nonirradiated) in comparison with adult worms 
recovered from infected mice. In general, adult male worms showed severe deformation in anterior and ventral suckers and a wide abnormal gynacoventral groove accompanied with increased loss of spines and shortage of adult worms in the immunized groups or those treated with PZQ. Similar changes were also obtained by El-Gawish and Moawad (2003). After vaccination, loss of spines enables the worms to move against the blood stream, since they hold the worm against the flow of the blood by being embedded within the wall of the vessel.

In the present study, PZQ was used as reference chemotherapy against schistosomal infection in order to evaluate the effectiveness of immunization of irradiated and non-irradiated schistosomula antigen. The results showed that administration of PZQ to infected mice induced remarkable reduction in ova count and worm burden, limited to moderate improvement in the physiological parameters as well as tegumental disruption, fusion of tegumental ridges, loss of spines and abnormal gynacoventral groove. These results are in accordance with Botros et al. (2005). According to Cheever et al. (2002) treatment of adult worms with PZQ caused vacuolation and disintegration of the tegumental surface. In addition to its effects on adult worms, PZQ acts both in vivo and in vitro on mature eggs of schistosomes laid in host tissues to be hatched. Sudden release of schistosome antigens from both adult worms and mature eggs after PZQ treatment presumably evokes extraordinary host immune responses, which are associated with the adverse effect of PZQ.

Concerning the histopathological studies, mice infected with alive $S$, mansoni cercariae showed drastic changes in liver architecture. Highly affected hepatocytes with focal parenchymal cellular infiltration giving picture of granuloma were clearly seen. These findings are in agreement with those of Pitella (1991) who stated that some schistosome eggs pass to the liver and lodging in the lungs leading to inflammatory reaction, granuloma formation and fibrosis. The present results also revealed marked dilatation and congestion of portal veins together with bile duct proliferation . A granuloma of infiltrating cells was observed around the portal structures and the portal tracts showed fibrous thickening. In connection with these observations, Abdel-Hadi and Talaat (2000) reported that shistosomiasis resulted in series of chronic inflammatory lesions produced in and around blood vessels by eggs or sometimes by adult worms which led to progressive fibrosis in the portal tract. According to Yamashita and Boros (1997) and Wyan et al. (2004), in shistosomiasis, the chronic granulomatous inflammation and reparative fibrosis in the liver are the major causative factors in the pathogenesis of the disease.

It is clear from this study that PZQ treatment is of benefit, but it has many side effects. Examination of liver sections of PZQ treated group showed signs of amelioration, where liver parenchyma and portal tracts showed little damage, less congestion and reduction in granuloma formation. However, vacuolar degeneration of hepatocytes and occurrence of necrotic foci were still observed. Furthermore, congested veins in the portal tracts were seen loaded with adult worms which caused damage and necrosis to the surrounding liver tissue. In this regard. Zhang et al. (1995) also observed pathological changes in livers of rabbits infected with schistosome cercariae and treated with PZQ. They indicated that if PZQ was given to rabbits in the early stage after infection, no apparent or only slight damage of the liver induced by the eggs was seen due to the fact that most or even all of the female worms were killed. In 2002, El-Shafei et al. reported that PZQ treatment of $S$. mansoni infected mice was effective in reducing the severity of the disease and in attenuating hepatic fibrosis particularly when the treatment starts early with a suitable dose.

Utzinger et al. (2000) stated that although PZQ is considered as the best schistosomicidal agent available today for the clinical management of schistosomiasis, patients were not completely cured and this may be due to repeated infection and treatment. So control of schistosomiasis can 


\section{Mona A. El-Gawish et al}

be achieved by sanitation, snail eradication or using vaccination. In the present study, immunization of mice with non-irradiated and irradiated antigen was examined. The results indicated that non-irradiated antigen induced severe degenerative changes in the livers of these animals. Focal necrosis and mild diffuse fatty degeneration were noticed. Moreover, cellular infiltration was well marked around the blood vessels and inbetween the degenerated hepatocytes. Aggregations of inflammatory cells forming granulomata were observed. The interstitial granulomas gradually organized leading to fibrosis. These results were supported by Bickle et al. (1979) who found no protection in mice immunized with non-irradiated schistosomula.

Meanwhile, immunization with irradiated antigen produced marked amelioration in the liver damage. There is very little inflammation and the hepatic architecture appeared mare or less normal. Groups of the adult worms were observed inside portal vein without any local reaction. Also, marked evidence of regeneration of parenchymal cells were seen. Mild periportal cellular infiltration without granuloma formation detected herein implying that irradiated antigen is more effective in minimizing the pathogenesis observed in infected group. Similarly, Molony et al. (1987) and Roushdy et al. (1997) recorded significant levels of protection in infected mice treated with irradiated antigen. Different doses of $\gamma$-rays ranged from 2-100 $\mathrm{K}$ rad have been used in preparation of irradiated vaccines. As reported by Villela et al. (1961), low doses of irradiation were effective, while Minard et al. (1979) and Lewis et al. (1984) deduced that maximal resistance was obtained only with high doses.

Furthermore, lungs of infected mice, as demonstrated in the present study, showed highly destructed bronchioles and engorged arteries. Thickening of interalveolar septa was seen as well as many alveoli appeared with shed destroyed epithelium. Peribronchiolar and perivascular fibrosis was observed together with aggregations of cellular infiltration.
Some of these aggregations were nodular due to granulomatous response. In agreement with these results, Warren et al. (1974) reported that granulomatous pulmonary arteritis was seen routinely in infected mice. However, Cheever et al. (2002) stated that granuloma in the mouse lung induced much less fibrosis than granulomas in the liver. The finding that the most intense inflammatory reactions were associated almost exclusively with schistosomula located in alveoli could be due to the triggering of inflammatory responses by host tissue damage resulting from breaching of the capillary-alveolar barrier ( Kassim et al., 1992),

On the other hand, the treatment with PZQ showed partial amelioration, where some alveoli and bronchioles appeared to be free of structural damage. However, severely degenerated bronchioles, thickened alveolar walls, extravasated RBCs and intense inflammatory foci with fibroblastic invasion were still noticed. In this concern, Liang et al. (2002) observed gross pathological lesions in lung of infected mice, but these lesions were markedly reduced post PZQ treatment. In spite of the beneficial effect of PZQ against schistosomiasis since it caused drastic changes in the worms and their ova, many pathological changes were detected in lung. These findings were well correlated with those of Utzinger et al. (2000) who deduced that patients would not completely accepted immunity against schistosomiasis even after PZQ had been administered three times and this may be due to reinfection.

Therefore, the present study aimed to prevent schistosomiasis and reinfection through immunization of mice with nonirradiated and irradiated antigens. However, the results showed no signs of amelioration with non-irradiated antigen, where serious adverse effects were still detected in lung tissue. In controversy, irradiated antigen produced an obvious amelioration as indicated by restoration of normal appearance of most alveoli and bronchioles apart from those associated with less cellular infiltration and pulmonary congestion. The present study documented marked 
deformed worms with reduced rate of egg deposition. These findings are in agreement with von Lichtenberg et al. (1985) as they elucidated that residual inflammatory foci might represent sites of worm elimination.

Taken together, the physiological, parasitological, immunological as well as histopathological observations recorded in this study indicated that the level of resistance of mice vaccinated with irradiated antigen appeared higher to some extent than that of mice treated with PZQ. Such resistance could be attributed to the significant reduction of worm burden accompanied with low egg output that deposited in liver and even those present in the intestine could not reach to the mature stage. Moreover, the worms seen lodged in the hepatic portal veins were almost highly damaged, consequently they failed to lay eggs. Thus, it could be speculated that the marked healing of the liver and lung lesions is well correlated to the rapid killing of the parasite and the prompt cessation of egg deposition by damaged worms.

Although experimental animal models have been very useful in allowing identification of various candidate vaccine antigens and demonstration of a range of potentially protective immune response, yet the response of animals to vaccine differs from one animal to another and none can be taken necessary to reflect the protective responses that might occur in man. So parallel studies on human (depending on recovered ova in stools) are very necessary. A large amount of work remains to be done including continued development and optimization of vaccine antigens or antigen cocktails or antigen plus chemotherapy in order to maximize the level of resistance against S.mansoni infection.

\section{References}

1. Abdel-Hadi A M and Talaat M (2000): Histological assessment of tissue repair after treatment of human schistosomiasis. Acta Trop., 77: 91-96.

2. Alonso $\mathbf{D}$, Munoz $\mathbf{J}$, Gascon $\mathbf{J}$ and Valls M E (2006): Failure of standard treatment with praziquantel in two returned travelers with Schistosoma haematobium infection. Am. J. Trop. Med. Hyg., 74: 342-344.

3. Arkin $H$ and Colton RR (1962): In Table for Statisticians, $9^{\text {th }}$ Edition, Barne and Noble Inc, New York.

4. Ashton M S, Noya O T and Rowe D S (2001): Effect of schistosomiasis on liver enzyme in mice infected with Schistosoma mansoni cercariae. Am. J. Trop. Med. Hyg., 62:55-64.

5. Bickle Q D, Dodinson T and James E.R. (1979): The effects of gamma irradiation on migration and survival of $S$. mansoni schistosomula in mice. Parasitology, 79: 223-230.

6. Botros S, Doughty B L, Shaker Z A and Akl M M (1996): Efficacy of an antipathology vaccine in murine schistosomiasis administered with and without chemotherapy. Int. J. Immunopharmacol., 18:707-718.

7. Botros S, Sayed H, El-Dusoki H and Sabry H (2005): Efficacy of mirazid in comparison with praziquantel in Egyptian Schistosoma mansoni-infected school children and households. Am. J. Trop. Med. Hyg., 72: 119-23.

8. Cheever A W, Jane A, Lenzi $B$ and Henrique L (2002): Experimental models of Schistosoma mansoni infection. Mem. Inst. Oswaldo. Cruz., 97: 917-940.

9. Davies S J, Lim K C, Blank R B and Kim J H (2004): Involvement of TNF in limiting liver pathology and promoting parasite survival during Schistosoma infection. Int. J. Parasitol., 34:27-36.

10. De Jesus A R, Magalhaes A, Miranda D G and Miranda R G (2004): Association of type 2 cytokines with hepatic fibrosis in human Schistosoma mansoni infection. Infec. Immun., 27(6):3391-3397.

11. Delgado V S, De Souza A C, Teixeira B C, Ventural $L$ and Orefice $F$ (2002): Retinal fluorescein contrast arrival time of young patients with the hepat-osplenic form of the Schistosomiasis mansoni. Mem. Inst. Oswaldo. Cruz., 1:161-164.

12. Drury $R$ A and Wallington E A (1980): Carleton's Histological Technique, $5^{\text {th }}$ ed., Oxford University Press. London, New York, Toronto, 1:653-661.

13. El-Gawish M A and Moawad M A (2003): Immunological studies on the mice vaccinated with irradiated cercaria and IL12 against Schistosoma mansoni infection. Egypt. J. Immunol., 10: 39-48.

14. El-Haieg M O Ibrahim I I and Zanaty M F (1997): Alpha feto-protein in adult normal 
bilharzial hepatic fibrosis and viral hepatitis in Egypt. J. Egypt. Med. Assoc., 60:699706.

15. El-Kady I M, Lotfy M, Badra G and ElMasry S (2005): Interleukin (IL)-4, IL-10, IL-18 and IFN-gamma cytokines pattern in patients with combined hepatitis $\mathrm{C}$ virus and Schistosoma mansoni infection. Scand. J. Immunol., 61 :87-91.

16. El-Shafei $M M$ M, Matter $M A$ and Afify $H$ A (2002): Parasitological and immunological changes in murine hepatic schistosomiasis before and after praziquantel treatment. J. Egypt. Soc. Parasitol., 32:551-560.

17. El-Shaikh K, Gabry $S M$ and Yousief $A$ Z (1998): Effect of reactive oxygen treatment on potency of Schistosoma mansoni worm antigens in induction of resistance to challenge infection in mice. Medical Journal of IAS, 11:321-325.

18. Fallon P G and Doenhoff M J (1994): Drug-resistant schistosomiasis: resistance to praziquantel and oxamniquine induced in Schistosoma mansoni in mice is drug specific. Am. J. Trop. Med. Hyg., 51:83-88.

19. Fallon P G Fookes $\mathbf{R} \mathbf{E}$ and Doenhoff $\mathbf{M} \mathbf{J}$ (1996): Protection of mice against Schistosoma mansoni infection by passive transfer of sera from infected rabbits. Parasite Immunol., 18 : 7-14.

20. Greenberg R M (2005): Are $\mathrm{Ca}^{2+}$ channels targets of praziquantel action?. Int. J. Parasitol., 35:1-9.

21. Harrison $\mathbf{R}$ A, Bickle $\mathbf{Q} \mathbf{D}$, Kaire $\mathbf{S}$ and James E R (1990): Immunization of baboons with attenuated schistosomula of Schistosoma haematobium : levels of protection induced by immunization with larvae irradiated with 20 and $60 \mathrm{Krad}$. Trans. R. Soc. Trop. Med. Hyg., 84 : 89-99.

22. Helmy A M, Abdel-Hady A A, ElShanawany $F$ and Hammam $O$ (2005): The pharmacological approach to reverse portal hypertention and hepatic schistosomal fibrosis in Egypt, control experimental study. J. Egypt. Soc. Parasitol., 35 : 731-750.

23. Henry R J (1976): Clinical Chemistry, Harper and Row, New York, pp. 181.

24. Hoffmann K F, Casper P, Cheever A W and Wyan T A (1998): IFN-gamma, IL-12 and TNF-alpha are required to maintain reduced liver pathology in mice vaccinated with Schistosoma mansoni eggs and IL-12. J. Immunol., 15: 4201-4210.

25. Hoffmann K F, James $\mathbf{S} \mathbf{L}$, Cheever A W and Wyan T A (1999): Studies with double cytokine-deficient mice revealed that highly polarized Th1 and Th2 type cytokine and antibody responses contribute equally to vaccine induced immunity to Schistosoma mansoni. J. Immunol., 15 : 927-938.

26. Kamel I A, Elwi A M, Cheever A W and Danner R (1978): Schistosoma mansoni and S. haematobium infections in Egypt. IV: hepatic lesions. Am. J. Trop. Med. Hyg., 39:999.

27. Kassim O O, Dean D A, Mangold L B, and von Lichtenberg F (1992): Combined microautoradiographic and histopathological analysis of the fate of challenge Schistosoma mansoni schistosomula in mice immunized with irradiated cercariae. Am. J. Trop. Med. Hyg., 47: 231-237.

28. Kumar V and Gryseels B (1994): Use of praziquantel against schistosomiasis: a review of current status. Int. J. Antimicrobial Agents, 4:313-320.

29. Leptak L L and Mckerrow J H (1997): Schistosoma egg granulomas and hepatic expression of TNF-alpha are depen-dent on immune priming during parasite maturation. J. Immunol., 158:301- 307.

30. Lewis F A, Stirewalt $M A$ and Leef $\mathbf{J} \mathbf{L}$ (1984): S. mansoni: vaccination of mice with $10 \mathrm{~K}$ rad irradiated cryopreserved schistosomules. Exp. Parasitol., 57:261-268.

31. Liang Y S, Coles G C, Dai J R, Zhu Y C and Doenhoff $M$ J (2002): Adult worm tegumental damage and egg-granulomas in praziquantel-resistant and-susceptible Schistosoma mansoni treated in vivo. J. Helminthol., 76 : 327-333.

32. Masson P (1929): Masson's trichrome stain. J. Tech. Meth., 12: 75.

33. Menson $\mathbf{E} \mathbf{N}$, Coulson $\mathbf{P} \mathbf{S}$ and Wilson $\mathbf{R}$ A(1989): Schistosoma mansoni. Circulating and pulmonary leucocytic responses related to the induction of protective immunity in mice by irradiated parasites. Parasitol., 98:43-55.

34. Minard P, Dean D A, Jacobson R H, Vannier W E and Murrell K D (1979): Immunization of mice with cobalt-60 irradiated S. mansoni cercariae. Am. J. Trop. Med. Hyg., 27:76-86.

35. Molony $\mathbf{N} \mathbf{A}$, Webbe $\mathbf{G}$ and Hinchcliffe $\mathbf{P}$ (1987): The induction of species-specific immunity against $S$. japonicum by exposure of rats to ultraviolet attenuated cercariae. Parasitol., 94 : 49-54.

36. Montenegro $\mathbf{S}$ M, Miranda $\mathbf{P}$, Mahanty $\mathbf{S}$ and Abath F G (1999): Cytokine production in acute versus chronic human schistosomiasis mansoni: the crossregulatory role of interferon-gamma and 
interleukin-10 in the responses of peripheral blood mononuclear cells and splenocytes to parasite antigen. J. Infec. Dis., 179 : 15021514.

37. Mountford A P, Harrop $\mathbf{R}$ and Wilson $\mathbf{R}$ A (1995): Antigens derived from lung-stage larvae of S. mansoni are efficient stimulators of proliferation and gamma interferon secretion by lymphocytes from mice vaccinated with attenuated cercariae. Infec. Immun., 63: 1980-1986.

38. Ozaki T, Inaba T, Sato $H$ and Nargis $M$ (1997): Schistosoma mansoni: Relocation of parasites to lungs from hepatic portal system in rodents. Southeast Asian, J. Trop. Med. Public Health, 28:581-587.

39. Pearce E J and James S L (1986): PostLung stage schistosomula of $S$. mansoni exhibit transient susceptibility to macrophages-mediated cytotoxicity in vitro that may relate to late killing in vivo. Parasite Immunol., 8: 513-527.

40. Pearce E J, Basch P F and Sher A (1986): Evidence that the reduced surface antigenicity of developing Schistosoma mansoni schistosomula is due to antigen shedding rather than molecule acquisition. Parasite Immunol., 8:79-94.

41. Pitella J E (1991): The relation between involvement of the central nervous system in schistosomiasis and the clinical forms of parasitosis. Am. J. Trop. Med. Hyg., 94:1521.

42. Ramaswamy K, Kumar $\mathbf{P}$ and He $\mathbf{Y}$ (2000): A role for parasite-induced PGE2 in IL-10-mediated host immunoregulation by skin stage schistosomula of Schistosoma mansoni. J. Immunol., 165:4567-4574.

43. Roushdy H M, El Gawish M A, AlSharkawi E M, Ashry M A and Abu- ElEla A M (1997): Gamma-irradiation cercarial homogenate of Schistosoma mansoni for immunization of mice against homologous challenge of bilharzial infection .Egypt J. Med. Sci., 18 : 561-582.

44. Sadler C H, Rutitzky L I, Stadecker M J and Wilson R A (2003): IL-10 is crucial for the transition from acute to chronic disease state during infection of mice with Schistosoma mansoni. Eur. J. Immunol., 33(4) : 880-888.

45. Scand J (1974): Determination of alkaline phosphatase. Clin. Lab. Invest., Soc. Clin. Chem., 33:291-301.

46. Schumann $G$ and Klauke $R$ (2003): Determination of aspartate amino transaminase (AST). Clin. Chim. Acta, 327:69-79.
47. Silveira A M, Gazzinelli G, Alves-Oliveira L F and Bethony J (2004): Human schistosomiasis mansoni: intensity of infection differentially affects the production of interleukin-10, interferon-gamma and interleukin-13 by soluble egg antigen or adult worm antigen stimulated cultures. Trans. R. Soc. Trop. Med. Hyg., 98 : 5145119.

48. Utzinger J, N'Gordan E K, N'Dri A, Lengeler $C$ and Tanner $M$ (2000): Efficacy of praziquantel against Schistosoma mansoni with particular consideration for intensity of infection`. Trop. Med. Int. Health, 5 : 771-778.

49. Vennervald B J, Kenty L Butterworth A E and Kariuki C H (2004): Detailed clinical and ultrasound examination of children and adolescent in a Schistosoma mansoni endemic area in Kenya: hepatosplenic disease in the absence of portal fibrosis. Trop. Med. Int. Health, 9:461-470.

50. Villela T B, Gomberg $\mathbf{H} \mathbf{G}$ and Could S E (1961): Immunization to $S$. mansoni in mice inoculated with irradiated cercariae. Sci., 1073-1075.

51. von Lichtenberg F. Correa-Oliveira R. and Sher A (1985): The fate of challenge schistosomula in the murine antischistosome vaccine model. Am. J. Trop. Med. Hyg., 34: 96-106.

52. Wales A, Fukumoto S, Otieno $M$ and Kusel J (1993): Effects of irradiation on surface carbohydrates of larvae of $S$. mansoni. Parasitol., 106:117-125.

53. Warren K S, Mahmoud A A, Bolos D I, Rall T W and Mandel M A (1974): In vivo suppression by cholera toxin of cellmediated and foreign body inflamma-tory responses. J. Immunol., 112 : 996-1007.

54. Wilson $R$ A and Coulson P A (1986): Migration of the schistosomula of Schistosoma mansoni in mice vaccinated with radiation attenuated cercariae, and normal mice. Parasitol., 92:101-110.

55. Wyan A, Eltoum I, Oswaldo I P and Cheever A W (1994): Endogenous interlukin 12 (IL-12) regulates granuloma formation induced by eggs of $S$. mansoni and exogenous IL-12 both inhibits and prophylactically immunizes against egg pathology. J. Exp. Med., 179 : 1551-1561.

56. Wyan A , Thompson R W, Cheever A W and Mentink-Kane $M \quad M \quad$ (2004): Immunopathogenesis of schistosomiasis. Immunol.,7510: 156-167.

57. Yamashita T and Boros D L (1997): 1L-2 production and granulomatous inflammation 


\section{Mona A. El-Gawish et al}

in murine Schistosomiasis mansoni. J. Immunol., 149: 3659-3664.

58. Yolles T K, Moore D V, Deguisti D and Ripsom C A (1947): A technique for the perfusion of laboratory animals for the recovery of schistosomes. J. Parasitol., 33:319.
59. Young D S (2001): Effects of Disease on Clinical Lab. Tests, $4^{\text {th }}$ ed., AACC.

60. Zhang C, Yang $Y$ and Xiao S (1995): 'Pathological changes in the livers of rabbits infected with schistosome cercariae and treated with artemether or praziquantel in the early stage of infection`. Sheng Chong Bing Za Zhi, 13:51-53. 


\title{
كفاءة التحصين بأنتيجينات مشعة ضد الإصابة بعدوى بلهارسيا المستقيم

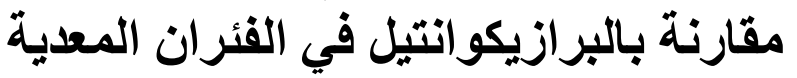

\author{
منى أحمد الجاويش ، منار نبيه حافظ ، فاطمة أحمد عيد* ، مها غازي سليمان* ، شيماء \\ ماهر خليل \\ قسم البيولوجيا الإشعاعية ـ المركز القومي لبحوث و تكنولوجيا الإشعاع ـ هيئة الطاقة \\ الذرية. \\ قسم علم الحيوان - كلية العلوم - جامعة الأزهر فرع البنات
}

استخدم في هذا البحث مائـة من ذكور الفئران البيضـاء التهى يتر اوح أوز انها بين 20- 25

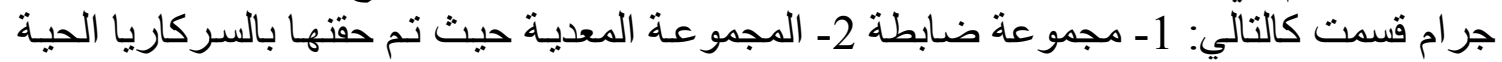

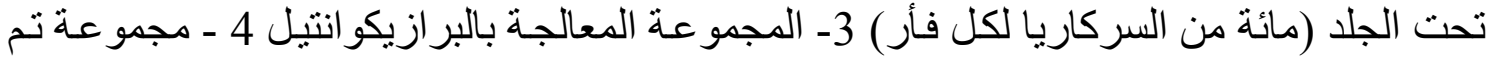

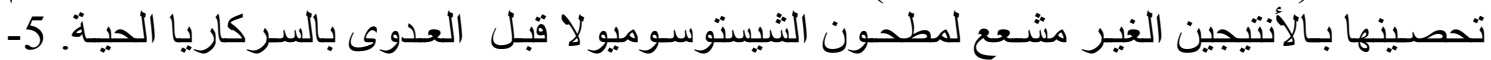

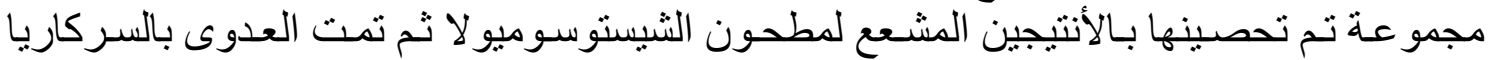
الحية.

ولقد أوضحت الدر اسات الفسيولوجية أن مجمو عـة الفئر ان المصـابة بالعدوى اكتسبت زيادة ملحوظة فى نشـاط إنزيمات الكبد بينمـا أدى التحصين بمطحون الثيستوسوميو لا المشععة عند 20

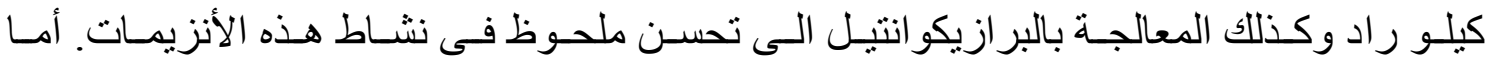

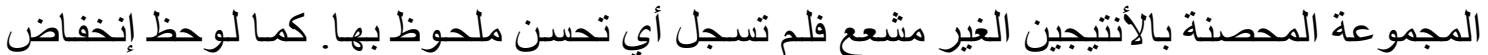

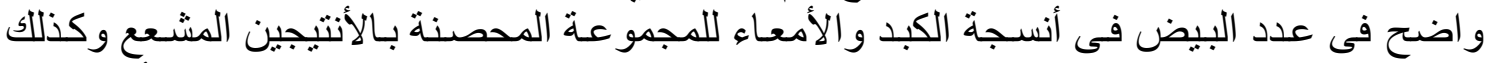

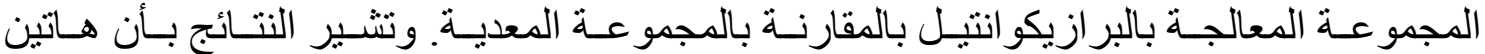
المجمو عتين قد إكتسبتا أعلى معدل للمقاومة ضد التد عدوى البلهارسيا.

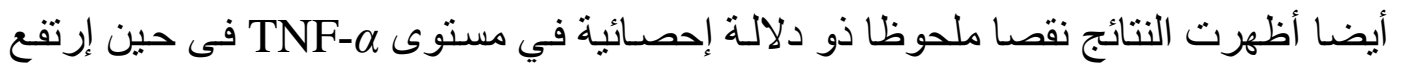
مستوى IL-10 ارتفاعـا واضـا في كل المجمو عات المختبرة مقارنـة بالمجمو عـة الضـابطة. كمـا

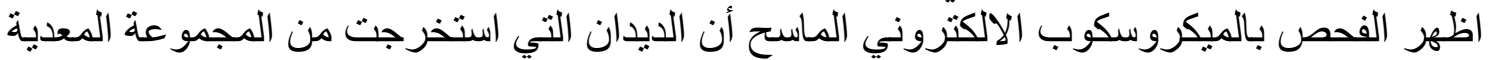

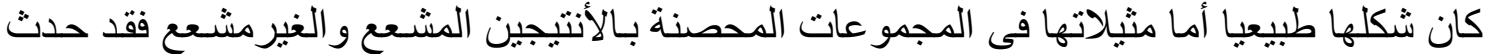

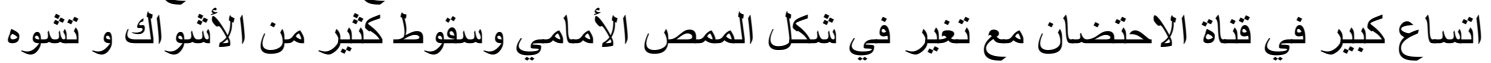

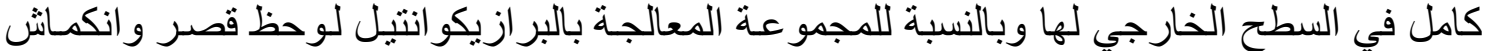

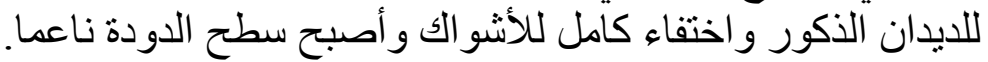

و على الجانب الأخر أظهر الفحص بالميكروسكوب الضـوئى لأنسجة كبد الفئر ان المصابة



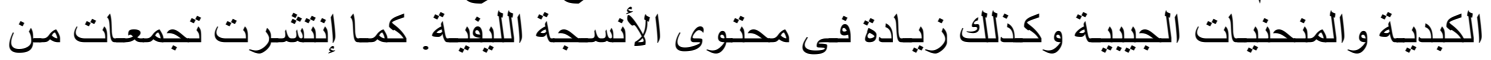



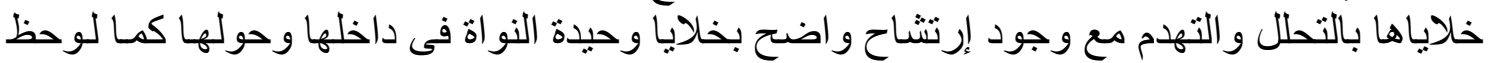
زيادة سمك جدر بعض الحويصلات الهوائية فى حين إعترى البعض الآخر مظاهر التمزق وتسـاقط

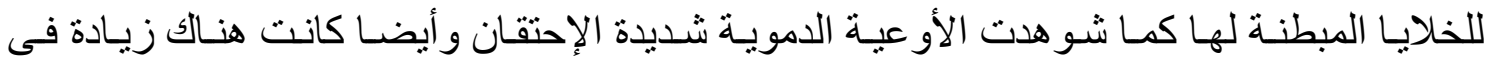

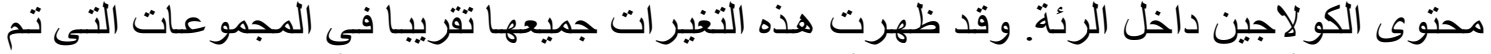

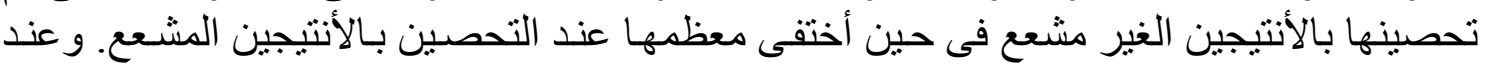




\section{Mona A. El-Gawish et al}

المعالجة بالبر ازيكو انتيل كان التحسن أقل وضوحا في أنسجة الكبد و الرئة حيث مـاز الت هناك مناطق تعانى من الإصابة.

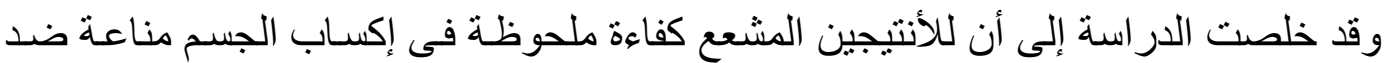

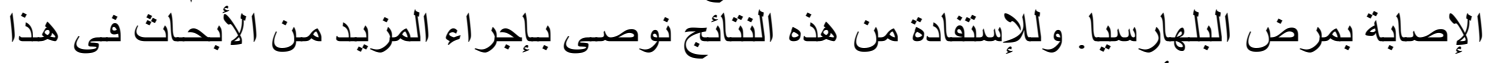

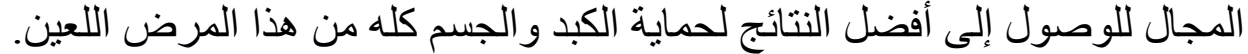

